\title{
Linguistic Overview of Dibra Phraseology
}

\section{Tefta Nuredini}

\author{
E-mail: ntefta@yahoo.com
}

\section{Doi:10.5901/ajis.2012.v2n4p205}

\begin{abstract}
Abastract:
The slang of the people is an inexhaustible treasure of phraseological units, a treasure that enriches and expands with new units, as well as it developing with uses meanings never encountered before. Day by day popular discourse is becoming the main source of the phraseological field, as by the quality and quantity. Such a phenomenon is widespread in Dibra speech. This paper consists in presenting a linguistic overview of Dibra phraseological structure. Our aim is through it to give a little bit, a picture of the syntactic constructions of this region phraseology, which is known for the strength of the word. Dibra allegory and phraseology are stylistic and figurative features of the local dialect, which has a grammatical system and a vocabulary of its own basic fund. Precisely, this is our goal, to show their linguistic structure in a syntactic plan. Dibra phraseology expresses not only the features of the national language, its development history and psychological -philosophical thought, but also its linguistic style. The latter one appears to infinity of the contents, forms, stylistic-emotional values and their ability to be connected with other parts. Our treatment will be as committed as ever to classify phraseological expressions under construction, namely; the phrase structure and sentence structure.
\end{abstract}

Keywords: parabolic speech, Dibra phraseology, syntactic structure, phrase structure, sentence structure.

\section{Introduction}

A part of phraseology of this area is also included in the publication with undisputed values in Albanian lexicology area, for example in the 'Glossary the Albanian phraseology', prepared by our prominent lexicologist Jani Thomai. But fearlessly say that, in its bay are also many new elements not included in previous editions. Namely, the latter will take an important place in this paper. Thus, the paper will focus on the introduction of new phraseological units of the area where I live, as well as those which are included in the book 'Dictionary with expressions and phraseological units from Dibra" from M. Buci. I think that the novelty of this paper is the behavior of structure and new phraseological content.

\section{How much is reflected the phraseological property?}

The most lively and powerful expression of Dibra art and culture, is its language and popular folklore. Their linguistic, ethnographic, cultural and artistic treasure is best preserved, despite the impacts of the traces left by strangers, proving so their autochthony, existence and relevance. However, it must be said, that Dibra is a non closed linguistic area. Due to its geographical position, have occurred linguistic contamination and interference of culture and traditions of the Macedonian and Slav world, which is observed especially in the border areas as well as in the province of Golloborda.

"The language of Dibra", goes beyond words, beyond the direct conception of expression. Her encoding surpasses the borders of the common language. Parabolic speech is known for centuries to Dibra and its people, and it is a natural tendency of a broad measure of people from different levels, who want to demonstrate the wisdom of their creative spirit.

In Dibra communication, the figurative discourse model, occupies the main place. In Dibra codes the word is used as nowhere used with unprecedented style and elegance. The people as a great master choose the appropriate word for every situation, expressing their opinion and judgment for political, economical, social 
and religious problems. Dibra phraseology is used mostly in spoken discourse. What is observed, not frequently, in the phraseological structure, is that we encounter dialect words, which are unified by content and form such as ;( I'u mbush mulla. I lujti mulla. U ba tërkuzë).

Dibra phraseology is perpetuated, not only in spoken discourse, but also in writing. We find it in its folklore values; songs, ballads, tales and fiction, especially in Dibra authors as; H. Stermilli, A. Ndreu, M. Buci, Xh. Martini etc.

In songs:

"Ka traj ditë se t'përgjoj n'udhë / Lule s'erdhe kurrë! / Kam lanë babën lak n'dishek / S'ëm ban udha shtek!" (folklore)

Është lak n'dishek (ill), adjectival phraseological unit. Structurally, constructive limb of the phraseological unit(lak) is an adjectival name.

In tales:

Këtij barriut i lujti mulla. (Ndreu, p. 75)

I lujti mulla (is in love), verbal phraseological unit. This phraseological unit is synonymous with the unit"i lujti zemra". These two phraseological units have similar limb luajti, while the mulla and zemra are not genuine synonymous words, but function as such in their phraseological structure.

In fiction;

"Por sytë tanë, me shkëlqimin e tyne të çuditshëm dhe me xixat që shkreptishin, shprazshin jashtë të tanë atë që bluheshin në tru e vlonte në zemër, në zemra aq herë të shitueme." (Stërmilli, p. 60)

bluhet në tru (think about s.th.)an adjectival phraseological unit. Structural Modeling is a two limb phraseological unit as; impersonal verb + noun.

a. "Janë të grisun petkash e të zbathun. (ibid. p. 147)

Janë të grisun petkash - (poor), adjectival phraseological unit. The meaning of the unit is kept by the limb with a quality function 'grisuna', expressed with an adjective.

b. "Më erdh shoum keç, e, aj farë baouri çi kishte nji kalë ment!.. - më tha nji grue dibrane kur më pa. (ibid. p. 262)

kishte nji kalë mend!.. (Smart), adjectival phraseological unit. The phraseology is synonymous with the other phraseology "Ishte kokë e madhe". Structural Modeling is a three limb phraseological unit. This phraseological unit has a 'nuclear' organization, i.e. the first and the third limb constitute the core kishte mend it means "smart" and constitutes the essence of the meaning. The second limb, obviously, has a semantic and syntactic connection with other that is constructive joints, and seems as facultative limbs.

In allegory

a. "Or Abaz, - i thirri nji malësor nga ana e majtë e Drinit malësorit tjetër në anëm e djathtë të Drinit, - a do t"i çojsh simjet bakëtinë në mal, apo do t'i mbajsh te shtëpia? - Me i çue due, bile përtej Korabit, por jemi pak kojshi e kemi frikë se na vdiren rrugës. - Veç bahi gati se u ndihmojmë ene ne, - $i$ tha tjetri. - Mirë, pra, sot nji javë, pa dalë drita, do t'i trazojmë bashkë." (Martin, p. 8) 
(Through this story Highlanders, in 1920, agreed in order to be raised against Yugoslav - Serb, who had occupied Dibra).

pa dalë drita $\sim$ (before the dawn,- early in the morning), adverbial phraseological unit. Structural Modeling is a sentence phraseological unit.

This can no way remain uninvolved in scientific publications. Here it is to be mentioned "Glossary of Albanian phraseology", prepared by Jani Thomai. In this work, as an illustration we can mention phraseological units, as; kanë lemë me...këmishë, u ba tërkuzë, morri mallet...

\section{New phraseological elements of the area}

The language of native people is an endless source of phraseological expressions, which in different contexts, gain an indisputable expressive value. There are social contexts from which they derive. Therefore, we always could face new phraseology, and new structures never encountered before. It should be noted that, in this north-eastern area (which is included in the southern gegerishte dialect, in the central gegerishte group speaking), there are also phraseological expressions, which has a very rare use, and can be considered as new elements. Let us here mention these examples.

a. Çan thënin e nxjerr mushknin (Çan thërijën e nxjerr mushkërijën) -(agile)adjectival phraseological unit. The structuring of the phraseological unist is coordination.

b. I ra lëmshi në shkozë - (get distracted), verbal phraseological unit. The structural Modeling is a three limb phraseological unit, as; verb+noun+noun.

c. Pret t'i vije prej oxhaku, a prej havaje. - (lazy), adjectival phraseological unit.

d. E tërheq shatin nga vetja. - (a miser person), adjectival phraseological unit. The structural Modeling is a three limb phraseological unit, as; verb+noun+noun.

e. Arra çuket e mani shkundet - (comprehend), verbal phraseological unit. The structural Modeling is a three limb phraseological unit. The syntactical order is in coordination.

f. Si peri, gëzofi - (similar), adjectival phraseological unit. The modeling is a phraseological unit based on comparison.

The phraseology of this region is of interest, for reasons that have syntactic indicators, related, necessarily, with regional elements, such as; phraseological units associated with the river, flora and fauna of the mountain environment, in any case, even with the toponymy of the province, that are of interest to Albanian phraseology in general. To illustrate we mention some; : fjalët lumë, bukën brumë; çdo lis ka rranjën e vet; e ka me kumbull e me grumull; e shet klyshin ma shtrenjt se qenin;; asht ba si ujk Prati; e rref era e Qafëmurrës; ranë si Rabdishtas në lesh;etj.

\section{Linguistic structure}

The Structure of phraseological units is simple. However, there is a great variety of structures; we mention here, two limbs structures or those many limbs, in a sentence form.

When the word is connected to a string of words other than semantic field, there is also the syntactic, after entering as part of various compound words. Some of them are created at the time when talking and are called 'free compound words.' In addition to these free compound words, language has also 'stable compound words', or the so-called phraseological units / frazeografike, who are historically created and used as a readymade unit. Typical examples in our speech, are constructed with phrase structure, but there are few of those that are sentence structured.

\section{Phraseological expressions with phrase structures.}

There are several types of phraseological units with phrase structure, according to the lexical-grammatical categories of their limbs. We will try to present the structures of this type, which are widely used and those which convey a greater emotional weight, when used either in oral whether in written discourse. 
1.a noun + noun $\sim$ Si koshare misri. (Buci, p. 95) - (fat), adjectival phraseological unit. The modeling is a phraseological unit with construction based on comparison. This phraseological unit has emerged from comparison through metaphor in lexicalization. Phraseology based on comparison with a stored comparative conjunction (si) are widely used in the speech of this region.

1.b verb+ verb I ranë patkojt. - (get tired), verbal phraseological unit. The phraseology is synonymous with the other one "I ranë këmbët".

1.c verb + noun + adverb $E$ përtyp fjalën mirë. (Buci, 63) - (deep thinking), verbal phraseological unit. This unit becomes an antonymous unit with the other one "E lëshon fjalën pa u menduar", antonym which is based on a common limb fjalen. This is the shaft limb of the two phraseological units.

1.d verb + verb Digjet e përdridhet. (Buci, f. 47) -(it doesn't change), verbal phraseological unit.

1.e verb + noun +adjective Shkeli në dërrasë të kalbur. - (make a mistake), verbal phraseological unit.

\section{Phraseological expressions with sentence structures.}

Such expressions, almost keep their construction of those words from which they derive. They are equivalent to the word by their categorical meaning and their function in discourse. Their meaning comes through complete and elliptical sentences. Just as in ordinary discourse, where complete sentences are constructed with the direct and indirect sequence, the same thing happens with the phraseological expressions too.

\section{2.a Phraseological expressions with a right sentence structure order.}

It is known that the position of the limbs in a sentence is determined by various factors; mainly by current limb, by stylistic reasons, and their syntactic function. The order is right, neutral, when the subject is the topic, and carries the logical emphasis, preceding the predicate, which is the core and keeps the emphasis of the phrase.

2. a.1. (Ai) E ka me gisht e me bisht. (Buci, p. 71) - (fraudulent), adjectival phraseological unit. Ai e ka me gisht e me bisht. The construction of the phraseological unit is in coordination. There are times when this unit is used with its incomplete form me gisht e me bisht, and the lexical grammatical meaning is adverbial (bad). The structural modeling is a two limb phraseological unit. The limbs are in coordination. $E$ bëri punën me gisht e me bisht.

2.a.2. T'i shkundë dardhat me t’pame (Buci, p. 41) - (skillful), adjectival phraseological unit. This is a "nuclear" organizational unit, where the limbs have a close semantic-syntactical connection and form a visible core, which carries the meaning of the unit. The core is formed by ti shkundë me t'pame, , and dardhat is a constructive limb, and looks like an optional limbs.

2.a.3. (Ai/ajo) Shkon trupthi e vjen zgupthi. (Buci, p. 169) - (behave badly), verbal phraseological unit. The structural modeling is a sentence phraseological unit. The limbs create a full antonym shkon vjen and contextual antonym trupthi zgupthi. This modeling is often encountered in spoken language.

2.a.5 Kërkon dardha në shëndre (Buci, p. 40) - (to ask the impossible), verbal phraseological unit. The modeling is a sentence structure phraseological unit.

\section{2.b Sentence structure phraseological unit with indirect order.}

Indirect order is a predicate-subject. The order is neutral when the predicate is expressed with a passive voice or non transitional verb.

2,b,1 Për dhëndërrin qeshin edhe trarët. (Buci, p. 47) - (everybody is happy), verbal phraseological unit. The modeling is a sentence structure phraseological unit.

2.b.2 Nuk i numërohen baltat (Buci, p. 26) - (evil/wicked), adjectival phraseological unit. Modeling is a sentence structure phraseological unit. 


\section{2.c Phraseological expressions with elliptical sentence structures}

Quite common are cases where the phraseological expression is built with elliptical sentences. The spoken and written speech with dense ellipse is a syntactical feature of the popular and conversational Albanian. The ellipse has psychological and logical roots and logical, and it is based on objective factors mainly in those cases where the message from the sender to receiver can be easily understood, when the direct perception of the recipient is realized, from the experience of the interlocutors, the language context, gestures, mimics, intonation, for emotional reasons, discursive situation and using the same and unchanged structure of different units, as;

2.c.1. Kryja n'tra e mendja hava - Characterizes someone who is tall, but immature in judgment and reasoning. The lexical-grammatical meaning is adjectival (immature)

2.c.2.(Vjen) Java shtatë, ai tetë. - Say to someone who comes often and tease you.

Ai vjen java shtatë e ai tetë = often. The lexical-grammatical meaning is adverbial (often).

2.c.2. Dorë shakull e zemër akull (Buci, p. 16) - it is used for people who think only for themselves, taking from others but gives nothing. The lexical-grammatical meaning is adjectival (miser).

2.c.3. Brryla dalë e gojë vale (Buci, p. 24) - a feature of s.b. that makes the hassle, who shows promotes wickedness. The lexical-grammatical meaning is adjectival (evil).

2.c.4. Sytë çakërr, punët bakërr -it is said to someone who is ugly and messy. The lexicalgrammatical meaning is adjectival (messy).

2.c.5. Pa baç torbe e pa rasë vorbe (Buci, p. 29) - Used to characterize a poor person. The lexicalgrammatical meaning is adjectival (poor).

2.c.6. Dorë shuk e shpinë pambuk - it is used to characterize someone who is stingy and does not bother working. The lexical-grammatical meaning is adjectival (miserly).

2.c.7. Dy bima në nji fajs, njena plas e qetra krajs. (Buci, p. 28) - It is used about two sisters who are married in the same tribe, but they do not go well with, arguing with each other. The lexical-grammatical meaning is adjectival (same).

The modeling of these units is with elliptical sentence structure. Their structure is either in coordination or asindete.

As it is noted, spoken phraseological units in Dibra are diverse, in the phrase structure, as well as in the sentence. In their entirety, most prevalent phraseological units are those with phrase structure, and, especially, those whose structure is built in comparison. While, in sentence structure phraseological units, the syntactic word order is free and authentic. In this group the most important part is occupied by phraseological expressions with elliptical sentence structure.

Being one of the most important elements that define the features of a language and maintain longer the traces of independence and tradition, it is comprehended why the phraseological study is important. Through them, we study their meaning nuances and the expressive - emotional value of words in general and of phraseological units in particular.

\section{Conclusions}

Firstly, as we have mentioned above, the phraseology of the language is a precious gem of the spoken language of a people, and, simultaneously, an indicator of its heritage, such as the Dibra phraseology, an inheritance of this people. Their use and creation has passed from mouth to mouth, carefully hewn from generation to generation, by coming to the Dibra speakers as a linguistic wealth to be further inherited and enriched. Indeed for the latter one is new phraseological units never encountered before.

Secondly, though, non linguistic situations are the source of idioms birth, they can be taken as language production, since they essentially have linguistic system elements. 
Thirdly, as the language changes occur, phraseological units change too. As a matter of fact, some of them disappear, and other arises. The trend of the birth of new phraseological units is based on phrase structure.

Fourthly, sentence structure phraseological units are encountered with the right, indirect order, and those with elliptical structure. Among them the most common, in oral and written discourse, are elliptical structure units.

Phraseological expressions are the spiritual wealth of dibra people, part of its great art and healthy tradition, evidence of talent and creative power, evidence of sharp speech and the expression of its culture. Phraseological expressions, with a rich and figurative language, with dexterous constructions and forms, by means of saving tools and poetic subtext, they not only satisfy the ordinary receiver if he is from Dibra or not, but they are also a study source for Albanian language researchers. I think that the area hosts a deeper exploration, in terms of phraseology.

\section{References}

ASHSH, Grammar 2, Tiranë, 2002,

Buci,M. Dictionary with frazeologjike phraseological expressions from Dibra, Tiranw, 2008.

Martini, Xh. Perlat e Dibrës, Edlor, Tiranë, 1999

Martini, Xh, Fytyra e miqësisë, "N. Frashëri", Tiranë, 1986

Ndreu, A, Allegorical Dibra tales , 8 Nëntori, Tiranë, 1983

Priftit, S, Studime Filologjike, 3, Tiranë, 1966

Stërmilli, H, Paths of Freedom, N. Frashëri, Tiranë,

Thomai, Jani, Çështje të frazeologjisë së gjuhës shqipe, Tiranë, 1981,

Thomai, Jani, Fjalor i frazeologjik i gjuhës shqipe, Tiranë, 1999

Thomai, Jani, Leksikologjia e Gjuhës Shqipe, Tiranë, 2006

Thomai, Jani, Modelimi në frazeologji, Studime frazeologjike, 1-4, Tiranë, 1997

Thomai, J, \& Lloshi, Xh, Paralele frazeologjike të shqipes me gjuhë të tjera të Ballkanit, në Studime mbi leksikun..., II, Tiranë, 1972, 